\title{
Characterization and Screening of Native Isolates of PSB and Azotobacter under in vitro Conditions
}

\author{
Hemlata Painkra, Tapas Chowdhury* and Narayan Prasad Verma \\ Department of Agricultural Microbiology, IGKV, Raipur-492006, Raipur, \\ Chhattishgarh, India \\ *Corresponding author
}

\section{Keywords \\ PSB, Azotobacter, BNF, Phosphorus solubilizing capacity. \\ Article Info \\ Accepted: \\ 17 April 2019 \\ Available Online: \\ 10 May 2019}

\section{A B S T R A C T}

The present study was conducted at Department of Agriculture Microbiology, College of Agriculture, IGKV, Raipur, C.G. during the year 2018-19 to characterize and screen different native isolates of PSB and Azotobacter. 14 microbial isolates were biochemically characterized and screened under in-vitro conditions for their plant growth promoting properties. Among 14 tested isolates Azoto-B-44, Azoto-146, Azoto-B-126, PSB-S-88, PSB-H-27, PSB-S-170, PSB-S-71, PSB-H-5, PSB-S-162 were shown positive results for TSI and Citrate test. PSB-172 and PSB-S-64 were shown positive for MR test and PSB-S88, PSB-S-71, PSB-H-5, PSB-S-165 and PSB-S-162 were found positive for Gelatin liquefaction test. Rest of all isolates was negative towards above tests. All the isolates were taken for their antibiotic susceptibility study. Some isolates were found susceptible for Tetracycline $(30 \mathrm{mcg})$ and streptomycin $(10 \mathrm{mcg})$. In N-fixation study of Azotobacter isolates Azoto-B-126 found higher N-fixer, it fixed $3.25 \mathrm{mg} \mathrm{N} / \mathrm{gm}$ of sucrose. Azoto-123, Azoto-146 and Azoto-B-126 found significantly superior and at par for N-fixing capacity over Azoto-B-44. Ten isolates of PSB were screened for their P-solubilizing capacity. PSB-H-5 was found highest P-solubilizer $(894.51 \mu \mathrm{g} / \mathrm{ml})$, however all the isolates found significantly superior for P-solubilizing capacity over control. All the PSB isolates were also tested for their solubilizing efficiency of phosphorus in the form of solubilization zone. PSB-H-27 was found highest solubilization efficiency with solubilization zone of 14 $\mathrm{mm}$ diameter, however it found at par with PSB-S-162, PSB-S-165, PSB-S-71, PSB-H-5 and PSB-S-170.

\section{Introduction}

Bio-fertilizers are the bio-inoculants of specific beneficial microorganisms that promote the growth and development of plant crops by converting the unavailable form of nutrients into available form. These biofertilizers also improve the soil fertility
(Sivasakthivelan and Saranraj, 2013). Biofertilizer contains living microorganisms which promote plant growth mainly by increasing the availability of primary nutrients (nitrogen and phosphorus) to the host plant. Organisms that are commonly used as biofertilizers component are nitrogen fixer, potassium and phosphorus solubulizer or with 
the combination of molds or fungi. They are the best alternative to the chemical fertilizers (Naz and Bano, 2010).

Azotobacter, a free living heterotrophic nitrogen fixing bacterium, belongs to the family Azotobacteriaceae (Becking, 1981). Azotobacter species are found in soil, water, rhizosphere etc. It is a gram-negative motile soil organism and can be isolated and cultured ex-situ conveniently. Azotobacter is a highly aerobic organism, which fixes atmospheric nitrogen asymbiotically (Tejera et al., 2005). Besides, nitrogen fixation, Azotobacter also produces growth hormones viz., auxin, cytokinin, thiamine, riboflavin, nicotine, indole acetic acid and gibberellins, thereby stimulating plant growth. Phosphorus is an essential element for plant development and growth. Plants acquire $\mathrm{P}$ from soil solution as phosphate anions. There are various types of soil microbes which can solubilize this fixed form of $\mathrm{P}$ and make it available to plants (Richardson, 2001). Application of phosphorus along with phosphate solubilizing bacteria (PSB) improve $\mathrm{P}$ uptake by plants and yield indicating that the PSB are able to solubilize phosphates and to mobilize phosphorus in crop plants.

The plant growth benefits due to the addition of PSB include increases in germination rate, root growth, yield, leaf area, chlorophyll content, tolerance to drought, shoot and root weight (Abbasi et al., 2015).

Biofertilizers are more effective in soil when sufficient population of effective microbes is used to prepare them. Screening of microbes is necessary to select the effective crop beneficial microbe(s).

Screening allows the discarding of many valueless microorganisms, at the same time it allows the easy detection of the most effective microorganisms (Sagervanshi et al., 2012).
Identification and characterization of microorganisms is a key part of the microbial management. This technique is useful to identify bacteria or other unknown microorganisms in the bacterial population. The aim of this study is to revive Azotobacter and PSB isolates of microbial repository of Dept. of Agril. Microbiology, College of Agriculture, Raipur, characterize them and through systematic screening select the best performing Azotobacter and PSB isolates for their further use in crop production.

\section{Materials and Methods}

\section{Collection of bacterial samples}

Bacterial samples were collected from Microbiology repository of Department of Agricultural Microbiology, College of Agriculture, Raipur, C.G.

\section{Sub-culturing of isolates}

Sub-culturing of phosphate solubilizing bacteria and Azotobacter, Pikovskaya's media and Jensen's agar media were used, respectively. The isolates were revived by inoculating them in respective broths and incubated for $72 \mathrm{hrs}$. After incubation, the containing PSB and Azotobacter isolates was streaked on respective media plates and incubated them at $28 \pm 2^{\circ} \mathrm{C}$ for 48 hours. Pure colonies were selected and transferred them to respective agar slants and preserved them at $4^{\circ} \mathrm{C}$ for further study.

\section{Study of phenotypic and biochemical properties of the collected isolates}

Pure cultures of the collected isolates were characterized using criteria of Bergey's Manual of Systematic Bacteriology (Brenner et al., 2005). The Following morphological and biochemical tests were used. 


\section{Phenotypic characterization}

The Pure isolates were tested for the following morphological properties in which different shapes, size, elevation, colony size; Colony pigmentation, Gram reaction and shape of cell were examined.

\section{Biochemical characterization}

The isolates were characterized using standard biochemical methods as given in Bergey's Manual of Systematic Bacteriology (2001). The Catalase test, MR-VP test, citrate test, urease test, Indole production test and gelatin liquefaction test were carried out. A very specialized test the Triple Sugar Iron Agar test was conducted in order to diagnose them for glucose, lactose, and sucrose fermentation along with peptone catabolization, gas and $\mathrm{H}_{2} \mathrm{~S}$ production ability (Blazevic and Ederer, 1975).

In vitro screening of Azotobacter isolates for their nitrogen fixing ability and PSB for their P-solubilizing capacity

Nitrogen fixing ability: nitrogen estimation by microkjeldhal method

The amount of nitrogen fixed by Azotobacter isolates was estimated by Microkjeldhal method given by Jackson (1967). The collected Azotobacter cultures were inoculated to $5 \mathrm{ml}$ of $\mathrm{N}$ free broth medium. It was inoculated for 48 hours. $1 \mathrm{ml}$ of this broth was inoculated to $50 \mathrm{ml} \mathrm{N}$ free broth medium and inoculated for 15 days. $20 \mathrm{ml}$ of this culture was used for nitrogen estimation by following the standard procedure of Microkjeldhal technique (Reis et al., 1994).

\section{Phosphorus solubilizing capacity}

The flask containing $50 \mathrm{ml}$ of aliquots of inoculated cultures of Pikovskaya's broth medium were filtered through Whatman No. 1 paper to remove insoluble phosphate and centrifuged at 10,000 rpm for 10-15 minutes. After centrifugation, $10 \mathrm{ml}$ aliquot was taken and $10 \mathrm{ml}$ of Barton's reagent was added and the volume made up to $50 \mathrm{ml}$. After 10 minutes, the resultant colour was read in a spectrophotometer using $420 \mathrm{~nm}$ wavelength (Koening and Johnson, 1942).

\section{Phosphate solubilization efficiency}

Sterilized Pikovskaya's media was poured into sterilized Petri plates, after solidification of the media; a pin point inoculation of the Petri plates was made on plates under aseptic conditions. The plates were incubated at $28^{\circ} \mathrm{C}$ for 7-10 days. Then the ability of PSM to solubilize the insoluble phosphate was studied by the determination of solubilization efficiency (SE).

Where,

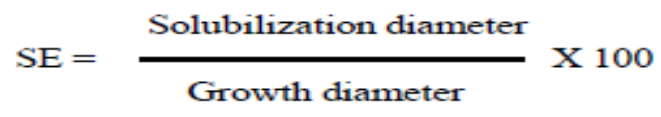

\section{Antibiotic study}

Antibacterial activity was carried out using disc diffusion method. The tests were conducted with 4 different antibiotic disc (Streptomycin-10mcg/disc, Tetracyclin$30 \mathrm{mcg} / \mathrm{disc}$, Penicillin-G-10mcg/disc, and Ampicillin-10mcg/disc). Antibiotic disc were placed at the center of the broth culture plates and incubated at $28 \pm 2{ }^{\circ} \mathrm{C}$ for 3-4 days. Antibiotic sensitivity was observed by measuring the hollow zone diameter of the studied organism.

\section{Results and Discussion}

The present research was conducted for characterizations of14 isolates which were obtained from the microbial repository of 
dept. of Agril. Microbiology, IGKV, Raipur and the isolates were screened for nitrogen fixing capacity and phosphate solubilizing capacity.

\section{Phenotypic characterization of selected isolates}

All the 14 isolates were selected for further phenotypic studies and were confirmed as Azotobacter and Phosphorus solubilizing Bacillus and Pseudomonas sp. based on morphological characteristics and their gram staining behaviour (Table 1 and Figure 1). Karpagam and Nagalakshmi (2014) also isolated bacteria from agriculture soils and reported the genera Bacillus, Pseudomonas and Azotobacter as PSB.

\section{Biochemical test}

A series of biochemical tests were carried out for a better understanding of the physiochemical functions going on within the cell. In this study, among different Azotobacter isolates Azoto-B-44, Azoto-146 and Azoto-B-126 shown positive results for TSI test and Citrate test. Similarly, among different PSB isolates PSB-S-88, PSB-H-27, PSB-S-170, PSB-S-71, PSB-H-5 and PSB-S162 shown positive results for TSI and Citrate tests.PSB-172 and PSB-S-64 found positive for MR test and PSB-S-88, PSB-S-71, PSBH-5, PSB-S-165 and PSB-S-162 found positive for Gelatin liquefaction test. Rest of all PSB isolates found negative in rest of all tests (Table 2 and Figure 2).

\section{In vitro screening of Azotobacter and PSB isolates}

\section{Nitrogen fixing ability}

The nitrogen fixing ability of 4 local Azotobacter isolates was tested for initial screening of the isolates. Statistically highest nitrogen fixing ability was observed in AzotoB-126 (3.250 mg N/gm of sucrose) followed by Azoto-146 which fixed $2.750 \mathrm{mg} \mathrm{N} / \mathrm{gm}$ of sucrose after fifteen days of incubation. Azoto-123, Azoto-146 and Azoto-B-126 found significantly superior and at par for $\mathrm{N}$ fixing capacity over Azoto-B-44. Similar findings were also reported by Bag et al., (2017) that nitrogen fixing capacity of Azotobacter under in vitro condition, ranges between $3.16-12.66 \mathrm{mg} \mathrm{N} / \mathrm{gm}$ of sucrose. Similarly Gupta et al., (1992) showed that Azotobacter can fix atmospheric nitrogen at 1.47 to 1.50 (Average, 1.49) $\mathrm{mg} \mathrm{N}$ per gm of carbon source, whereas, Gondotra et al., (1998) found the range as 13.3 to $21.6 \mathrm{mg} \mathrm{N} / \mathrm{g}$ glucose (Table 3 ).

\section{Phosphorus solubilizing capacity}

All 10 isolates were screened for their potential to solubilize the phosphate. All isolates showed much or less variations in their potential for phosphate solubilization ranging from $263.72 \mu \mathrm{g} \mathrm{P} / \mathrm{ml}$ to $894.51 \mu \mathrm{g}$ $\mathrm{P} / \mathrm{ml}$ as per result recorded in table 4 and presented by bar diagram in figure. The isolates PSB-H-5 showed the highest phosphate solubilizing capacity i.e. $894.51 \mu \mathrm{g}$ $\mathrm{P} / \mathrm{ml}$ followed by PSB-H-27 and PSB-S-71 which solubilized $803.92 \mu \mathrm{g} \mathrm{P} / \mathrm{ml}$ and 768.08 $\mu \mathrm{g} \mathrm{P} / \mathrm{ml}$, respectively, whereas the isolate PSB-S-64 (263.72 $\mu \mathrm{g} \mathrm{P} / \mathrm{ml})$ was showing the least potential. All the PSB isolates found significantly higher of P-solubilizing capacity over control (Table 4). Sharon et al., (2016) also reported that PSB isolates have the similar character of P-solubilization activity ranges between $328 \mathrm{mg} \mathrm{P} / \mathrm{L}$ to $956 \mathrm{mg} \mathrm{P} / \mathrm{L}$.

\section{Phosphate solubilization efficiency}

All the PSB isolates were examined for their ability to solubilize phosphate sources on agar media supplemented with tri-calcium phosphate. These isolates formed a clear zone 
diameter of between $10-14 \mathrm{~mm}$ and the largest clear zone diameter of $14 \mathrm{~mm}$ was recorded in PSB-H-27 and the least clear zone was obtained in PSB-172 and PSB-S-64 i.e. $10 \mathrm{~mm}$. Similarly, highest solubilization efficiency was recorded in PSB-H-27 which was 100 percent (Table 5 and Figure 3). Similar results were found by Selvi et al., (2017) that Phosphate solubilizing bacteria were able to produce $0.2 \mathrm{~cm}$ to $1.0 \mathrm{~cm}$ of solubilization zone. Solubilization efficiency (SE) varied from 13.04 percent to 85.71 percent on 7 days of incubation period.

\section{Antibiotic sensitivity of isolates}

On the basis of the pattern of antibiotic response, all the bacterial isolates were distinguishable from each other. Azoto-B126, Azoto-123, Azoto-146, PSB-H-5, PSBS-170, PSB-H-27 and PSB-S-71 observed sensitive towards Tetracycline $(30 \mathrm{mcg} / \mathrm{disc})$ with the inhibition zone of diameter 24, 11, 17, 37, 36, 38 and $34 \mathrm{~mm}$, respectively.
Whereas, Azoto-B-126, Azoto-B-44 and Azoto-146 found sensitive towards Streptomycin $(10 \mathrm{mcg} / \mathrm{disc})$ with the inhibition zone of diameter 19, 23 and $18 \mathrm{~mm}$ respectively (Table 6 and Figure 4). Similar results found by Gupta et al., (2005) that isolate L-11 and L-20 showed resistance to antibiotic discs of Kenamycin $(30 \mu \mathrm{g})$, Gentamycin $(30 \mu \mathrm{g})$ and Ampicillin discs $(10 \mu \mathrm{g})$. Promising rhizobial isolate L-4 showed maximum zone of inhibition (zone dia. $25.3 \mathrm{~mm})$ with Kenamycin $(30 \mathrm{mcg})$ and with Gentamycin (30 $\mathrm{mcg})$. Isolate L-3 showed maximum susceptibility (zone dia. $23.0 \mathrm{~mm}$ ) might be due to more fusaric acid production (Singh and Saxena, 2002).

Kumar and Raghuram (2014) also recorded that solubilization of phosphorus with zone of range 12-18 mm was recorded in Azotobacter and PSB isolates and maximum solubilization efficiency of $125 \%$ was recorded while it is between $40-75 \%$ in rest of all strains.

Table.1 Morphological characteristics and gram staining behaviour of isolates

\begin{tabular}{|c|c|c|c|c|c|c|}
\hline \multirow[t]{2}{*}{ S.No. } & \multirow{2}{*}{$\begin{array}{c}\text { Microorganisms } \\
\text { Isolate No. }\end{array}$} & \multicolumn{4}{|c|}{ Colony morphology } & \multirow{2}{*}{$\begin{array}{l}\text { Gram staining } \\
\text { Gram reaction }\end{array}$} \\
\hline & & Colour & Forms & Margin & Elevation & \\
\hline 1. & Azoto-123* & White & Circular & Entire & Convex & - \\
\hline 2. & Azoto-B-44* & White & Circular & Entire & Convex & - \\
\hline 3. & Azoto-146* & White & Circular & Entire & Convex & - \\
\hline 4. & Azoto-B-126* & White & Circular & Entire & Convex & - \\
\hline 5. & PSB-S-162** & Yellow & Circular & Undulate & Raised & - \\
\hline 6. & PSB-S-71** & Yellow & Circular & Undulate & Raised & - \\
\hline 7. & PSB-S-64** & White & Irregular & Undulate & Raised & + \\
\hline 8. & PSB-172** & White & Irregular & Undulate & Raised & + \\
\hline 9. & PSB-S-170** & Yellow & Circular & Undulate & Raised & - \\
\hline 10. & PSB-S-87** & White & Irregular & Undulate & Raised & + \\
\hline 11. & PSB-H-5** & White & Irregular & Undulate & Raised & + \\
\hline 12. & PSB-H-27** & Yellow & Circular & Undulate & Raised & - \\
\hline 13. & PSB-S-88** & Yellow & Circular & Undulate & Raised & - \\
\hline 14. & PSB-S-165** & White & Irregular & Undulate & Raised & + \\
\hline
\end{tabular}


Table.2 Biochemical tests of isolates

\begin{tabular}{|c|c|c|c|c|c|c|c|c|c|}
\hline \multirow[t]{3}{*}{ S.No. } & \multirow[t]{3}{*}{ Isolate No. } & \multicolumn{8}{|c|}{ Biochemical characterization } \\
\hline & & \multirow{2}{*}{$\begin{array}{c}\text { Catalase } \\
\text { test }\end{array}$} & \multirow{2}{*}{$\begin{array}{l}\text { TSI } \\
\text { Test }\end{array}$} & \multirow{2}{*}{$\begin{array}{c}\text { Urease } \\
\text { test }\end{array}$} & \multirow{2}{*}{$\begin{array}{c}\text { Citrate } \\
\text { test }\end{array}$} & \multirow{2}{*}{$\begin{array}{c}\text { Indole } \\
\text { production } \\
\text { test }\end{array}$} & \multicolumn{2}{|c|}{ MR-VP Test } & \multirow{2}{*}{$\begin{array}{c}\text { Gelatin } \\
\text { Liquefaction test }\end{array}$} \\
\hline & & & & & & & MR Test & VP Test & \\
\hline 1. & Azoto-123 & - & - & - & + & - & - & - & - \\
\hline 2. & Azoto-B-44 & - & + & - & + & - & - & - & - \\
\hline 3. & Azoto-146 & - & + & - & + & - & - & - & - \\
\hline 4. & Azoto-B-126 & - & + & - & + & - & - & - & - \\
\hline 5. & PSB-S-88 & - & + & - & + & - & - & - & + \\
\hline 6. & PSB-H-27 & - & + & - & + & - & - & - & - \\
\hline 7. & PSB-S-170 & - & + & - & + & - & - & - & - \\
\hline 8. & PSB-172 & - & - & - & - & - & + & - & - \\
\hline 9. & PSB-S-64 & - & - & - & - & - & + & - & - \\
\hline 10. & PSB-S-71 & - & + & - & + & - & - & - & + \\
\hline 11. & PSB-H-5 & - & + & - & + & - & - & - & + \\
\hline 12. & PSB-S-165 & - & - & - & - & - & - & - & + \\
\hline 13. & PSB-S-162 & - & + & - & + & - & - & - & + \\
\hline 14. & PSB-S-87 & - & - & - & - & - & - & - & - \\
\hline 15. & Control & - & - & - & - & - & - & - & - \\
\hline
\end{tabular}

MR=Methyl red $(+)=$ Positive $\quad$ VP=Voges-Proskauer $\quad(-)=$ Negative $\quad$ TSI=Triple sugar iron

Table.3 N-fixing capacity of Azotobacter isolates in N-free Jensen's liquid medium

\begin{tabular}{|c|c|c|}
\hline S.No. & Isolate No. & N-fixed (mg N/gm of sucrose) \\
\hline $\mathbf{1 .}$ & Azoto-123 & 2.400 \\
\hline $\mathbf{2 .}$ & Azoto-146 & 2.750 \\
\hline $\mathbf{3 .}$ & Azoto-B-126 & 3.250 \\
\hline $\mathbf{4 .}$ & Azoto-B-44 & 2.050 \\
\hline $\mathbf{5 .}$ & Control & 0.035 \\
\hline & CD $(5 \%)$ & 0.184 \\
\hline
\end{tabular}

Table.4 Phosphorus solubilizing capacity of different PSB isolates

\begin{tabular}{|c|c|c|}
\hline S.No. & Isolate No. & P-solubilized $(\boldsymbol{\mu g} \mathbf{~ P / m l )}$ \\
\hline $\mathbf{1 .}$ & PSB-S-162 & 375.88 \\
\hline $\mathbf{2 .}$ & PSB-172 & 278.43 \\
\hline $\mathbf{3 .}$ & PSB-S-88 & 361.76 \\
\hline $\mathbf{4 .}$ & PSB-H-5 & 894.51 \\
\hline $\mathbf{5 .}$ & PSB-S-64 & 263.72 \\
\hline $\mathbf{6 .}$ & PSB-S-170 & 576.47 \\
\hline $\mathbf{7 .}$ & PSB-S-87 & 316.67 \\
\hline $\mathbf{8 .}$ & PSB-S-71 & 768.08 \\
\hline $\mathbf{9 .}$ & PSB-H-27 & 803.92 \\
\hline $\mathbf{1 0 .}$ & PSB-S-165 & 471.57 \\
\hline $\mathbf{1 1 .}$ & Control & 214.29 \\
\hline
\end{tabular}




\section{\begin{tabular}{l|r}
$\mathrm{CD}(5 \%)$ & 39.55
\end{tabular}}

Table.5 Solubilization of tri-calcium phosphate by different PSB isolates

\begin{tabular}{|c|c|c|c|c|}
\hline S.No. & Isolate No. & $\begin{array}{c}\text { Growth diameter } \\
(\mathbf{m m})\end{array}$ & $\begin{array}{c}\text { Solubilization } \\
\text { diameter }(\mathbf{m m})\end{array}$ & $\begin{array}{c}\text { Solubilization } \\
\text { efficiency } \\
\mathbf{( \% )}\end{array}$ \\
\hline $\mathbf{1 .}$ & PSB-S-165 & 7 & 13 & 85 \\
\hline $\mathbf{2 .}$ & PSB-S-162 & 8 & 13 & 62 \\
\hline $\mathbf{3 .}$ & PSB-S-71 & 7 & 13 & 85 \\
\hline $\mathbf{4 .}$ & PSB-H-27 & 7 & 14 & 100 \\
\hline $\mathbf{5 .}$ & PSB-H-5 & 7 & 13 & 85 \\
\hline $\mathbf{6 .}$ & PSB-S-87 & 6 & 11 & 83 \\
\hline $\mathbf{7 .}$ & PSB-S-88 & 8 & 12 & 50 \\
\hline $\mathbf{8 .}$ & PSB-S-170 & 8 & 13 & 62 \\
\hline $\mathbf{9 .}$ & PSB-172 & 7 & 10 & 42 \\
\hline $\mathbf{1 0 .}$ & PSB-S-64 & 7 & 10 & 42 \\
\hline & CD(5\%) & & 2.5 & 2.8 \\
\hline
\end{tabular}

Table.6 Determination of antibiotic susceptibility of different bacterial isolates

\begin{tabular}{|c|c|c|c|c|c|c|c|c|c|}
\hline \multirow[t]{3}{*}{ S.No. } & \multirow[t]{3}{*}{ Isolate No. } & \multicolumn{8}{|c|}{ Antibiotic } \\
\hline & & \multicolumn{2}{|c|}{ Ampicillin (10mcg) } & \multicolumn{2}{|c|}{ Penicillin (10mcg) } & \multicolumn{2}{|c|}{$\begin{array}{l}\text { Tetracycline } \\
\text { (30mcg) }\end{array}$} & \multicolumn{2}{|c|}{$\begin{array}{l}\text { Streptomycin } \\
(10 \mathrm{mcg})\end{array}$} \\
\hline & & Sensitivity & $\begin{array}{l}\text { Zone dia. } \\
\quad(\mathrm{mm})\end{array}$ & Sensitivity & $\begin{array}{l}\text { Zone } \\
\text { dia. } \\
\text { (mm) }\end{array}$ & Sensitivity & $\begin{array}{l}\text { Zone } \\
\text { dia. } \\
\text { (mm) }\end{array}$ & Sensitivity & $\begin{array}{l}\text { Zone dia. } \\
(\mathrm{mm})\end{array}$ \\
\hline 1. & Azoto-B-126 & $\mathrm{R}$ & 0.0 & $\mathrm{R}$ & 0.0 & $S$ & 24.0 & $S$ & 19.0 \\
\hline 2. & Azoto-123 & $\mathrm{R}$ & 0.0 & $\mathrm{R}$ & 0.0 & $\mathrm{~S}$ & 11.0 & $\mathrm{R}$ & 0.0 \\
\hline 3. & Azoto-B-44 & $\mathrm{R}$ & 0.0 & $\mathrm{R}$ & 0.0 & $\mathrm{R}$ & 0.0 & S & 23.0 \\
\hline 4. & Azoto-146 & $\mathrm{R}$ & 0.0 & $\mathrm{R}$ & 0.0 & $\mathrm{~S}$ & 17.0 & $\mathrm{~S}$ & 18.0 \\
\hline 5. & PSB-S-165 & $\mathrm{R}$ & 0.0 & $\mathrm{R}$ & 0.0 & $\mathrm{R}$ & 0.0 & $\mathrm{R}$ & 0.0 \\
\hline 6. & PSB-H-5 & $\mathrm{R}$ & 0.0 & $\mathrm{R}$ & 0.0 & S & 37.0 & $\mathrm{R}$ & 0.0 \\
\hline 7. & PSB-S-87 & $\mathrm{R}$ & 0.0 & $\mathrm{R}$ & 0.0 & $\mathrm{R}$ & 0.0 & $\mathrm{R}$ & 0.0 \\
\hline 8. & PSB-S-88 & $\mathrm{R}$ & 0.0 & $\mathrm{R}$ & 0.0 & $\mathrm{R}$ & 0.0 & $\mathrm{R}$ & 0.0 \\
\hline 9. & PSB-S-170 & $\mathrm{R}$ & 0.0 & $\mathrm{R}$ & 0.0 & S & 36.0 & $\mathrm{R}$ & 0.0 \\
\hline 10. & PSB-172 & $\mathrm{R}$ & 0.0 & $\mathrm{R}$ & 0.0 & $\mathrm{R}$ & 0.0 & $\mathrm{R}$ & 0.0 \\
\hline 11. & PSB-H-27 & $\mathrm{R}$ & 0.0 & $\mathrm{R}$ & 0.0 & $\mathrm{~S}$ & 38.0 & $\mathrm{R}$ & 0.0 \\
\hline 12. & PSB-S-71 & $\mathrm{R}$ & 0.0 & $\mathrm{R}$ & 0.0 & $\mathrm{~S}$ & 34.0 & $\mathrm{R}$ & 0.0 \\
\hline 13. & PSB-S-162 & $\mathrm{R}$ & 0.0 & $\mathrm{R}$ & 0.0 & $\mathrm{R}$ & 0.0 & $\mathrm{R}$ & 0.0 \\
\hline 14. & PSB-S-64 & $\mathrm{R}$ & 0.0 & $\mathrm{R}$ & 0.0 & $\mathrm{R}$ & 0.0 & $\mathrm{R}$ & 0.0 \\
\hline 15. & Control & $\mathrm{R}$ & 0.0 & $\mathrm{R}$ & 0.0 & $\mathrm{R}$ & 0.0 & $\mathrm{R}$ & 0.0 \\
\hline
\end{tabular}


Fig.1 Colony morphology of isolates

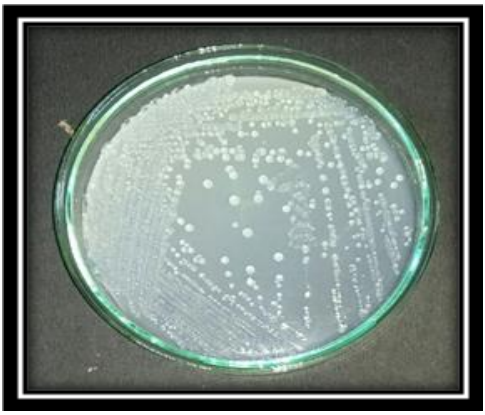

Growth of Azotobacter on Jensen's media

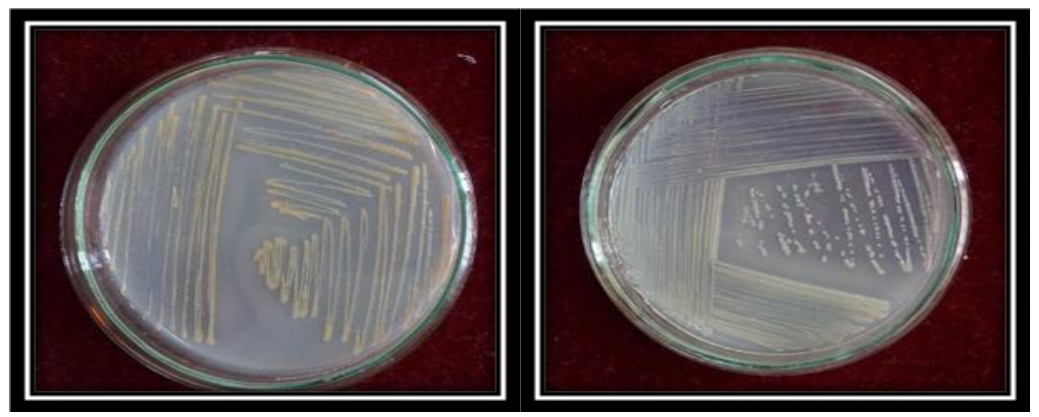

Growth of PSB on Pikovskaya's media

Fig.2 Biochemical characterization of isolates

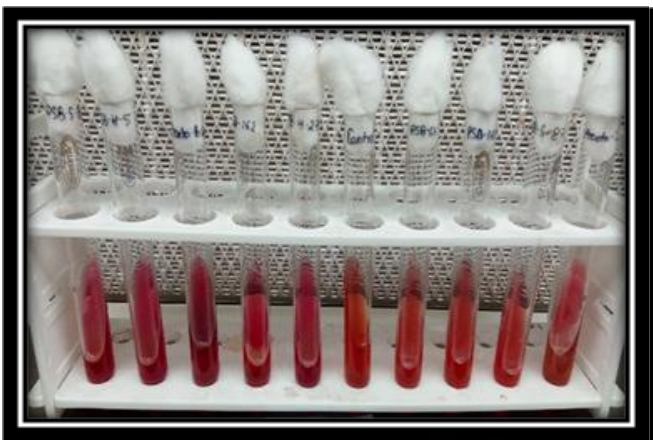

Triple sugar Iron (TSI) test

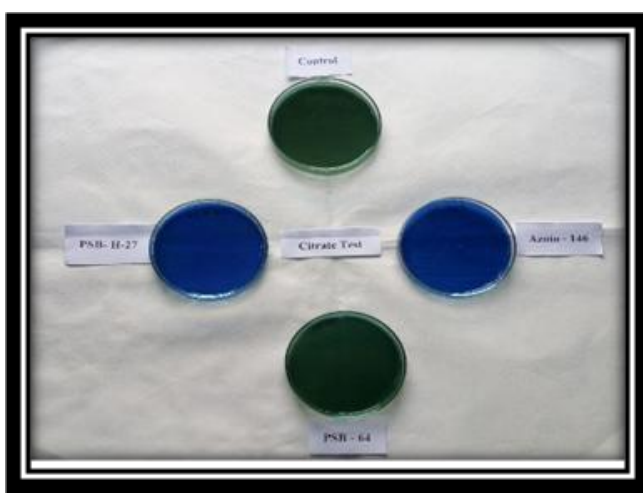

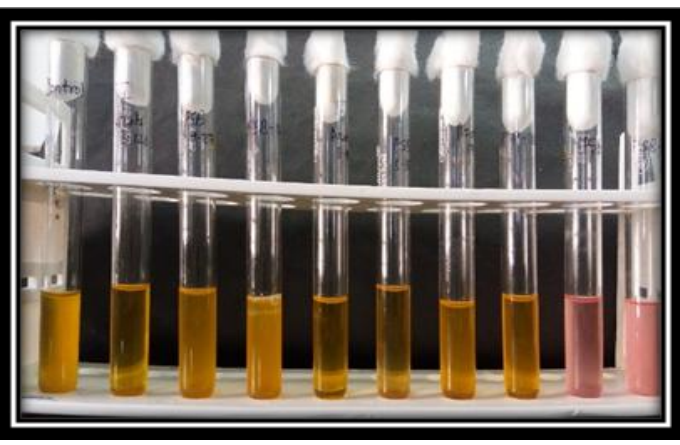

Methyl red test

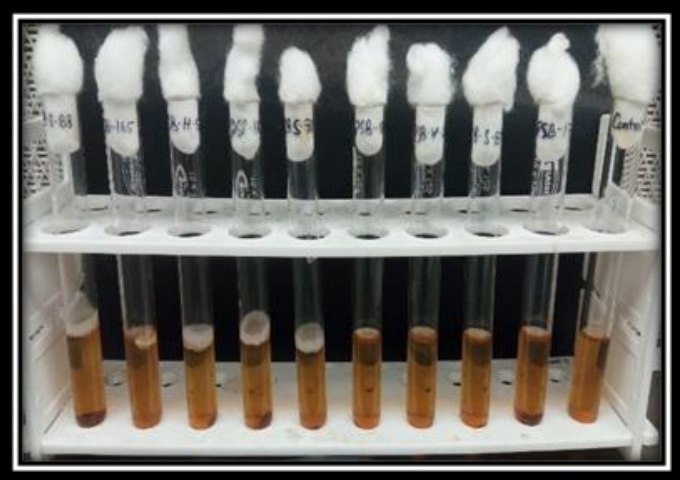


Citrate test

Fig.3 Growth of solubilization zone by PSB isolates
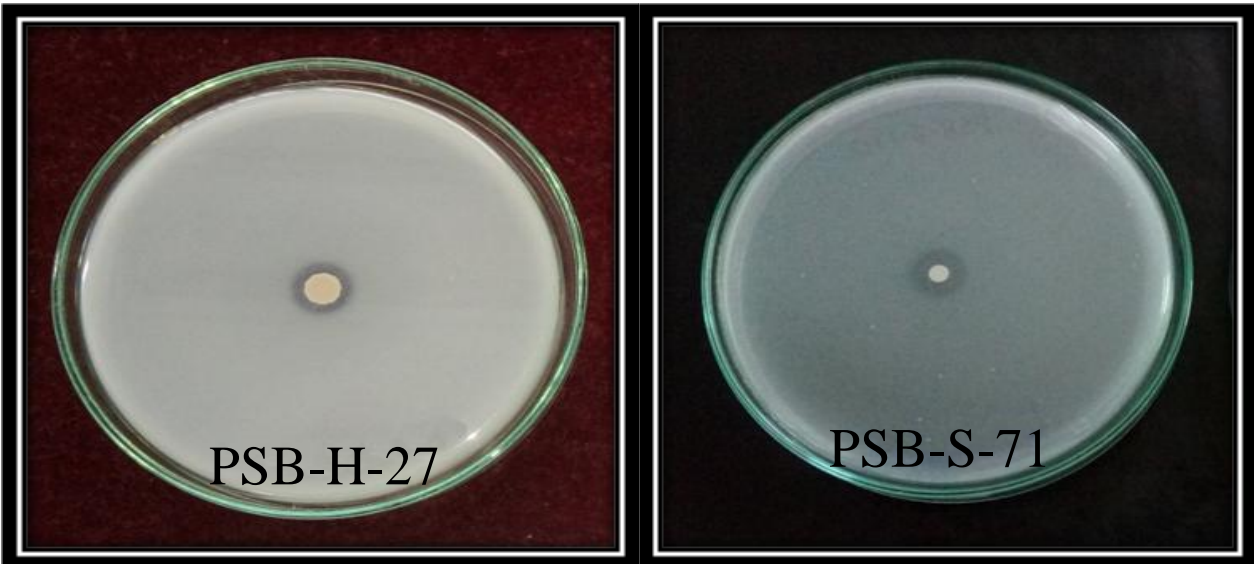

Fig.4 Antibiotic response of isolates
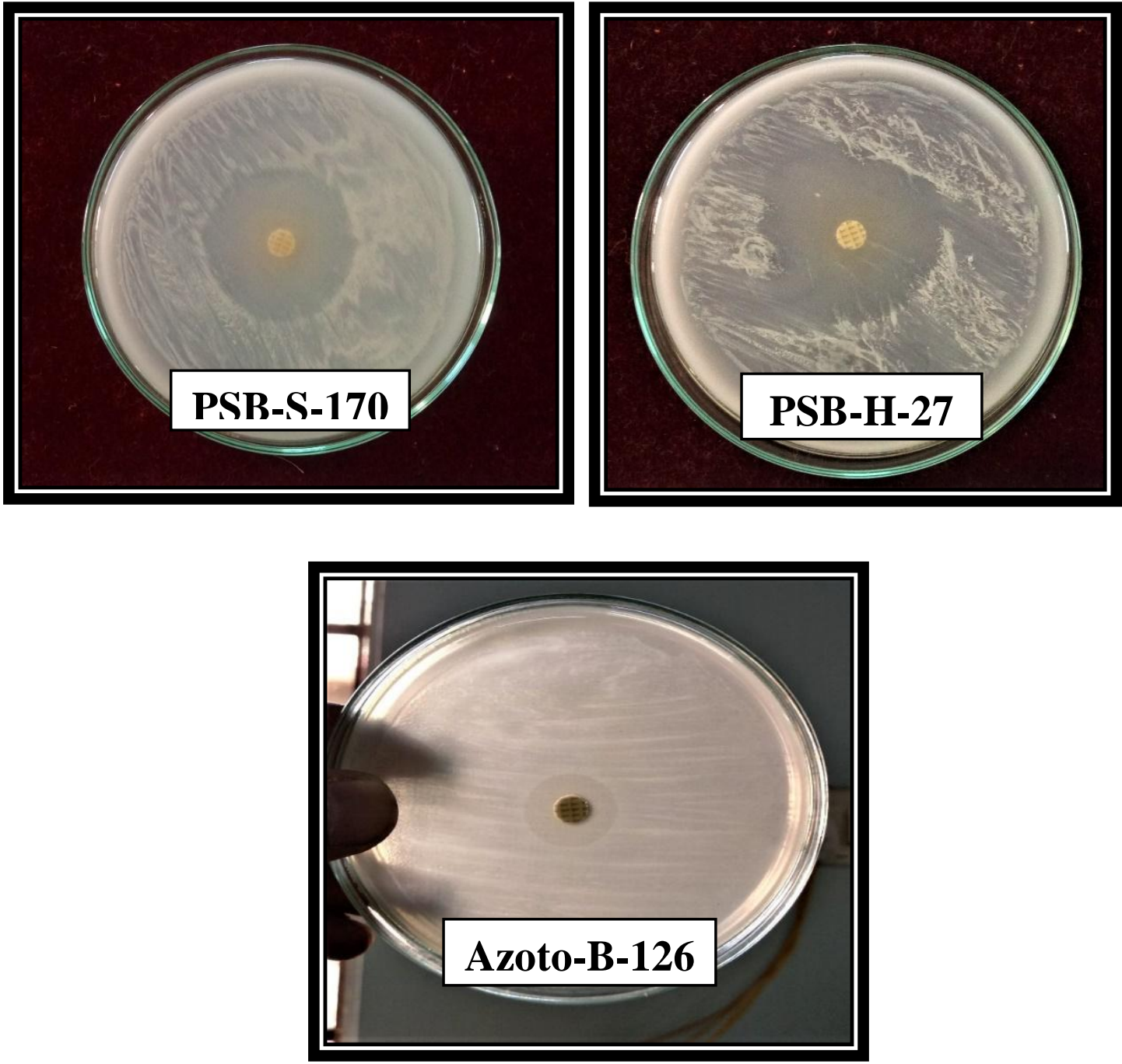
B. cepacia and B. ferrariae showed the best activities of solubilization for all source evaluated. The results obtained by $B$. ferrariae confirm that from Valverde et al., (2006), who isolated this organism from rock phosphate mines and considered it a great potential solubilizer.

It was concluded from the present study that native isolates showed variation in their character during different biochemical studies, screening and their antibiotic response. Due to their capacity of nitrogen fixing and phosphorus solubilization, the isolates can be exploited in future as biofertilizers for the improvement of crop productivity.

\section{Acknowledgement}

I am thankful to Department of Agricultural Microbiology, Indira Gandhi Krishi Vishwavidyalaya, Raipur, C.G., India for providing all the facilities to conduct my research work.

\section{References}

Abbasi, M. K., Musa, N., and Manzoor, M. 2015. Phosphorus release capacity of soluble $\mathrm{P}$ fertilizers and insoluble rock phosphate in response to phosphate solubilizing bacteria and poultry manure and their effect on plant growth promotion and $\mathrm{P}$ utilization efficiency of Chilli (Capsicum annum L.). Biogeosci. Discuss., 12: 18391873.

Bag, P. B., Panda, P., Paramanik, B. Mahato, B. and Choudhury, A. 2017. Atmospheric nitrogen fixing capacity of Azotobacter isolates from Cooch Behar and Jalpaiguri districts soil of West Bengal, India. Int. J. Curr. Microbiol. App. Sci., 6(3): 1775-1788.

Becking, J.H. 1981. The family
Azotobacteraceae. In: Starr MP, Stolp $\mathrm{H}$, Triiper HG, Balows A, Schlegel HG, editors. The Prokaryotes, vol. 2. Berlin, Heidelberg: Springer Verlag. p. 795-817.

Blazevic, D. J. and Ederer, G. M., Principles of biochemical tests in diagnostic microbiology, Wiley and Company, New York, 1975; 13-45.

Brenner, D.J., Krieg, N. R. and Staley, J.T. 2005. Volume two. The proteobacteria. Part A. Introductory Essays. In G. M. Garrity (ed.), Bergey's Manual of Systematic Bacteriology, Second Edition. Springer-Verlag, New York, Pp. 1304.

Gandotra, V., Gupta, R. D. and Bhardwaj, K. K. R. 1998. Abundance of Azotobacter in great soil groups of north-west Himalayas. J. Indian. Soc. Soil Sci., 46(3): 379-383.

Gupta, R.D., Tripathi, B.R., Awasthi, K.R. and Bhat, M.I. 1992. Microbial activities of rice soil profiles of northwest Himalayas. Oryza, 29: 127- 130.

Gupta, S. B., Choudhury, T., Tedia, K. and Singh, A. K. 2005. Exploiting rhizobium as biocontrol agent for wilt causing fungi. Ann. Pl. Protec. Sci., 13(1): 213-269.

Karpagam, T. and Nagalakshmi, P. K. 2014. Isolation and characterization of Phosphate solubilizing microbes from agricultural soil. Int. J. Curr. Microbiol. App. Sci., 3(3): 601-614.

Koenig, R.A. and Johnson, C.R. 1942. Colorimetric determination of phosphorus in biological materials. Ind. Eng. Chem. Anal., 14: 155-156.

Kumar, G. K. and Raghuram, M. 2014. Phosphate solubilizing Rhizobia isolated from Vigna trilobata. American Journal of Microbiological Research, 2(3): 105-109.

Naz, I. and Bano, A. 2010. Biochemical, 
molecular characterization and growth promoting effects of phosphate solubilizing Pseudomonas sp. isolated from weeds grown in salt range of Pakistan. Plant Soil, 334(1-2): 199207.

Peter, H. A. 2001. Bergey's Manual of Systematic Bacteriology. Vol. 1: 8388.

Reis, V.M., Olivares, F.L., and Dobereiner, L. 1994: Improved methodology for isolation of Acetobacter diazotrophicus and confirmation of its endophytic habitat. World J. Microbiol. Biotechnol., 10: 401-405.

Richardson, A. E. 2001. Prospects for using soil microorganisms to improve the acquisition of phosphorous by plants. Australian Journal of Plant Physiology, 28: 897-906.

Sagervanshi, A., Kumari P., Nagee, A. and Kumar, A. 2012. Isolation and characterization of phosphate solublizing bacteria from Anand agriculture soil. International Journal of Life Sciences and Pharma Research, 23: 256-266.

Selvi, K. B., Paul, J. J. A., Vijaya, V. and Saraswathi, K. 2017. Analyzing the Efficacy of Phosphate Solubilizing Microorganisms by Enrichment Culture Techniques. Biochem Mol
Biol J., Pp. 3:1.

Sharon, J. A., Hathwaik, L. T., Glenn, G. M., Imam, S. H., and Lee, C. C. (2016). Isolation of efficient phosphate solubilizing bacteria capable of enhancing tomato plant growth. J. Soil Sci. Plant Nutr. 16, 525-536.

Singh, R. and Saxena, V. C. 2002. A comparative evaluation of fusaric acid production by Fusarium solani and $F$. equisethi. causing wilt of cauliflower. Ann. Pl. Protec. Sci., 10: 394-396.

Sivasakthivelan, P. and Saranraj, P. 2013. Azospirillum and its formulation: A Review. Intl. J. Microbiol. Res., 4 (3): 275-287.

Tejera, N., Lluch, C., Martınez, M. V. and Lopez, J. G. 2005. Isolation and characterization of Azotobacter and Azospirillum strains from the sugarcane rhizosphere. Plant and Soil, 270: 223-232.

Valverde, A., Burgos, A., Fiscella, T., Rivas, R., Velazquez, E., Rodriguez, C. and Igual, J. M. 2006. Differential effects of co inoculations with Pseudomonas jessenii PS06 (a phosphate solubilizing bacterium) and Mesorhizobium ciceri $\mathrm{c}-2 / 2$ strains on the growth and seed yield of chickpea under greenhouse and field conditions. Plant Soil, 287: 43-50.

\section{How to cite this article:}

Hemlata Painkra, Tapas Chowdhury and Narayan Prasad Verma. 2019. Characterization and Screening of Native Isolates of PSB and Azotobacter under In-vitro Conditions. Int.J.Curr.Microbiol.App.Sci. 8(05): 2058-2068. doi: https://doi.org/10.20546/ijcmas.2019.805.239 